\title{
To Assess the Job-Related Difficulties and Dissatisfaction of Asha Workers in Selected Rural Area
}

\author{
Vaishali Deoraoji Taksande1, Priyanka Anil Ashtankar2, Chetna Rajendra Bansod³, Ashwini Vilas Bawane ${ }^{4}$, \\ Pratiksha Sankal Burchunde ${ }^{5}$, Diksha Vinayak Dudhe 6 , Madhavi Dharmpal Gawande ${ }^{7}$ \\ 1,2, 3, 4,5, 6,7 Department of Nursing, Datta Meghe Institute of Medical Sciences (Deemed to Be University), \\ Smt. Radhikabai Meghe Memorial College of Nursing, Sawangi Meghe, Wardha, Maharashtra, India.
}

\section{ABSTRACT}

\section{BACKGROUND}

Accredited social health activists (ASHAs) are the components of National Rural Health Mission (NRHM) programme. ASHA are the grass root level workers and the success of NRHM depends on the efficiency of ASHA workers' performance. Our aim was to assess the job-related difficulties and dissatisfaction of ASHA workers.

\section{METHODS}

Descriptive survey approach was used in this study and the sampling technique was purposive technique. Data was collected using structured questionnaire to assess the job difficulties and modified Cronbach's jobs satisfaction scale was used to assess the satisfaction of the ASHA workers. The study sample was 50 ASHA workers from Anganwadi of a rural area, under the child development project, office Tahsil, Samudrapur. The total number of villages in Tahsil was 154 and total Anganwadi's were 152 and out of 152 Anganwadi's 90 were selected randomly. The average number of Anganwadi female workers weas 1 to 3 in Wardha district.

\section{RESULTS}

24 (48\%) ASHA workers knew their duties regarding the health education, 11 (22 $\%)$ ASHA workers had the problem of not having a proper travelling facility and 16 (32\%) ASHA workers solved their problems by meeting with authority regarding the job satisfaction, 33 (66\%) ASHA workers had satisfaction with their jobs; whereas, 14 (28\%) were neutral.

\section{CONCLUSIONS}

The study highlighted the problems faced by ASHA workers and their satisfaction related to the job. If well-equipped functional health system exists it can improve the ability of ASHA workers to perform their role effectively and also raise their credibility and trust in the community.

\section{KEY WORDS}

Job Difficulties, Job Dissatisfaction, Rural Area, Role and Reasonability of ASHA, Problem Faced by ASHA, Community Health Workers
Corresponding Author: Dr. Vaishali Deoraoji Taksande, Professor, Department of OBGY Nursing, Datta Meghe Institute of Medical Sciences (Deemed to Be University), Smt. Radhikabai Meghe Memorial College of Nursing, Sawangi Meghe, Wardha, Maharashtra, India.

E-mail:vtaksande@gmail.com

DOI: $10.14260 /$ jemds/2021/20

How to Cite This Article:

Taksande VD, Ashtankar PA, Bansod CR, et al. To assess the job-related difficulties and dissatisfaction of asha workers in selected rural area. J Evolution Med Dent Sci 2021;10(02):98-101, DOI:

$10.14260 /$ jemds $/ 2021 / 20$

Submission 19-09-2020,

Peer Review 14-11-2020,

Acceptance 20-11-2020,

Published 11-01-2021.

Copyright (C) 2021 Vaishali Deoraoji Taksande et al. This is an open access article distributed under Creative Commons Attribution License [Attribution 4.0 International (CC BY 4.0)] 


\section{BACKGROUND}

Community health volunteer schemes are considered vital for increasing community participation and access to the health care system. An ASHA is a woman selected by the community, resident in the community and who is trained, deployed, and supported to function in her own village to improve the health status of the people through securing their access to health care services. ${ }^{1-2}$ Being lay workers, the governance structure, including their selection, incentives, and community ownership, and their performance in health and community development, has been identified as critical issues that need to be monitored. It is, therefore, imperative to know what kind of ASHA workers are in place and what work they are doing. This has implications for the role / utility of community health workers in several settings where health systems are traditionally weak. ${ }^{3}$

Accredited social health activist (ASHAs) are community health workers created as part of the National Rural Health Mission (NRHM) by the Ministry of Health and Family Welfare of the Government of India. ${ }^{4}$

India has taken initiatives that '(ASHAs) in every village'. (ASHAs) are the backbone of NRHM and are proposed for the village to be chosen and accountable. They need to introduce prevention, promotional and health care facilities to the rural community. Much more emphasis was given on the enrolment and training of (ASHAs) during the initial phase. Now we need to look at the results and challenges, problems faced by (ASHA) i.e. ill-equipped dispensaries, scarcity of resources, irregular incentives, workload, nonmaterialization of things, failure to achieve target, inadequate support from leaders, and no value of ASHAs. For most of ASHAs the finance gained from their work is very less as compared to their hard work. ${ }^{5}$

The National Rural Health Mission launched female community health worker accreditation social health activist (ASHA) who serves as a mediator between the community and the public health system. In NRHM ASHA Worker should be place at grass root level so rate of (ASHA) critical at Grass root level problem faced by ASHA) workers. It will affect the performance of (ASHA) Workers and low incentives or lacks of incentives are the main problem faced by them. ${ }^{6}$

Job satisfactions of the (ASHA) workers naturally depend on the economic, social and cultural situation. Those (ASHA) workers who cannot get a sufficient wage will face problem. This problem puts the (ASHA) far away from satisfied. ${ }^{7}$

It is evident that ASHAs were not having clarity regarding their roles and responsibilities as per the NRHM guidelines. Hence, quality training programs and more efforts regarding sensitizing and motivating ASHAs may be helpful for improving their performance. Provision of fair monetary incentives and regularization of incentives can be effective in motivating (ASHAs) for participating efficiently in health-care delivery system. ${ }^{8}$

\section{METHODS}

The study used descriptive survey approach. In this study subjects were ASHA workers. The sample size for study consisted of 50 (ASHA) workers in a selected Anganwadi in rural area. The child development project, office Tahsil Samudrapur. The total villages in Tahsil were 154 and total Anganwadi's were 152 and out of 152 Anganwadi's 90 were selected randomly. An average of one to three female workers were available in each Anganwadi of Wardha district. After obtaining informed consent from subjects, IEC letter no. 8498, data collection was done from $30^{\text {th }}$ December 2019 to $18^{\text {th }}$ January 2020 . Data was collected using structured questionnaire to assess the job difficulties and modified Cronbach's jobs satisfaction scale to assess the satisfaction of the (ASHA) workers was used. Score of 5 was given for strong satisfaction, score 4 was given for satisfaction, score 3 was given for neutral, score 2 was given for dissatisfaction and score 1 was given for strong dissatisfaction. ${ }^{10}$

\section{Statistical Analysis}

Statistical analyses performed using SPSS software version 22. Routine descriptive statistical analysis was done.

\section{RESULTS}

\begin{tabular}{|c|c|c|}
\hline Demographic Variables & $\begin{array}{c}\text { No of ASHA } \\
\text { Workers }\end{array}$ & Percentage (\%) \\
\hline \multicolumn{3}{|c|}{ Age in Years } \\
\hline $20-25$ years & 3 & 6 \\
\hline $26-30$ years & 13 & 26 \\
\hline $31-35$ years & 27 & 54 \\
\hline 36 - 40 years & 7 & 14 \\
\hline \multicolumn{3}{|c|}{ Marital Status } \\
\hline Married & 43 & 86 \\
\hline Unmarried & 7 & 14 \\
\hline \multicolumn{3}{|c|}{ Education } \\
\hline Secondary & 15 & 30 \\
\hline Higher Secondary & 26 & 52 \\
\hline Graduation & 9 & 18 \\
\hline Post-Graduation & 0 & 0 \\
\hline \multicolumn{3}{|c|}{ Monthly Family Income (Rs) } \\
\hline $1000-1500 \mathrm{Rs}$ & 24 & 48 \\
\hline $1501-2000 \mathrm{Rs}$ & 12 & 24 \\
\hline $2001-2500 \mathrm{Rs}$ & 9 & 18 \\
\hline $2501-3000$ Rs & 5 & 10 \\
\hline \multicolumn{3}{|c|}{ Working Experience } \\
\hline 6 months & 7 & 14 \\
\hline 1 year & 24 & 48 \\
\hline$\geq 2$ years & 19 & 38 \\
\hline $\begin{array}{r}\text { Table 1. Percentage } \\
\text { According to De }\end{array}$ & $\begin{array}{l}\text { Distribution o } \\
\text { aphical Varia }\end{array}$ & $\begin{array}{l}\text { HA Workers } \\
N=50\end{array}$ \\
\hline
\end{tabular}

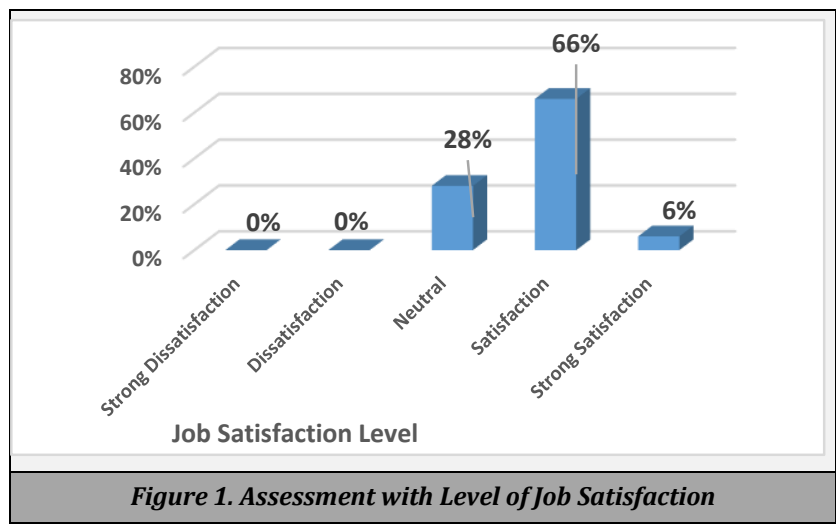

Distribution according to their age group; 13 (26\%) were in 20 - 25 years, 27 (54\%) in 26 - 30 years. Majority that is $43(86 \%)$ of the (ASHA) workers were married and most of (ASHA) workers, $26(52 \%)$ were educated up to $12^{\text {th }}$ 
standard. 12 (24\%) had 1501 - 2000 Rs. 9 (18\%) of the (ASHA) workers had monthly family income of 2001 - 2500 Rs. 24 (48\%) of the (ASHA) workers had work experience of 1 year and 19 (38\%) of them had work experience of two or more than two year.

\section{Assessment of Job-Related Satisfaction of ASHA Workers}

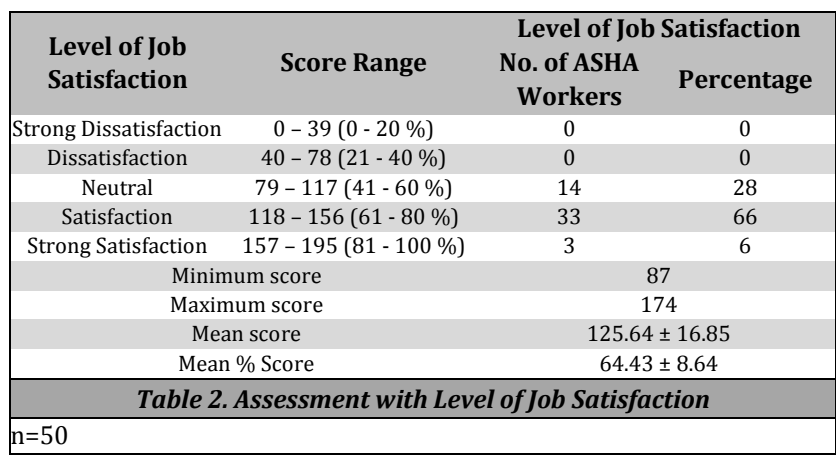

Fourteen (28\%) of the (ASHA) workers had neutral responses regarding job satisfaction, $33(66 \%)$ of them were satisfied with their job whereas only $3(6 \%)$ of them were strongly satisfied with their job.

\section{Assessment of Job Difficulties of ASHA Workers}

\begin{tabular}{|ccc|}
\hline Job Difficulties & $\begin{array}{c}\text { No. of ASHA } \\
\text { Workers }\end{array}$ & Percentage \\
What are your Duties and Responsibilities as ASHA & \\
Health education regarding health & 24 & 48 \\
scheme & 24 & 48 \\
ANC registration & 2 & 4 \\
Any health problems & 9 & 18 \\
What are the Problems faced by ASHAs while Performing their Duties \\
Unable to cooperate & 22 & 44 \\
Do not trust on them & 11 & 22 \\
Inability to travelling facility & 8 & 16 \\
Due to workload from home & 8 & 16 \\
What Interventions are ASHAs following to Overcome their Problems & 32 \\
Guidance on health care & 16 & 18 \\
Solving problem by meeting & 9 & 34 \\
Discuss problem with higher authority & 17 & 26 \\
Provide free open service & 13 & 20 \\
How effective the Interventions followed by ASHAs to Overcome their Problem \\
Arrange the program and information & 10 & 24 \\
given & 12 & 30 \\
\hline Improving one's work & 15 & \\
Time management & & \\
Issues are solved & Table 3 . Assessment with Job Difficulties & \\
\hline & &
\end{tabular}

According to their duties and responsibilities, 24 (48\%) of them knew their duties and job responsibilities regarding health education scheme. 24 (48 \%) knew about the antenatal care (ANC) registration in clinic. Majority of them, $22(44 \%)$ had problem about people not trusting on them and only 11 (22\%) had problem about no proper travelling facilities.

The percentage wise distribution about interventions done to overcome their problems, 16 (32\%) solved problems by meeting, whereas 17 (34\%) had provided free open service to people as intervention to overcome their problem.
Percentage wise distribution of effectiveness of interventions to overcome their problems, 13 (26\%) had arranged the health program and gave information about health. 15 (30\%) had improved their skill and knowledge to solve any issue or problem.

\section{DISCUSSION}

In the present study, 33 (66 \%) ASHA workers were satisfied with their jobs whereas almost $52 \%$ of ASHAs were dissatisfied with job and $61 \%$ were unhappy with their performance-based remuneration. Job satisfaction has to be increased with a corresponding increase in incentives while developing strategies to ease the process of payments. ${ }^{11}$

One another studies show that $39.29 \%$ lacked job satisfaction. They reveal that they were dissatisfied with inadequate remuneration and troubled by lack of essential medicine supply. ${ }^{12}$

In present study most of the subjects were satisfied similarly one study shows that $75 \%$ ASHA workers satisfied with their job. Job satisfaction has been defined as a pleasurable emotional state resulting from the appraisal of one's job an affective reaction to one's job. It is simply how people feel about their jobs and different aspects of the job, the extent to which people satisfaction or dissatisfaction their job. It suggests that job satisfaction is an important indicator of how employees feel about their jobs. A major part of man's life is spent in work which is a social reality and social expectation to which man seem to confirm. Even then only economic motive has never satisfied men. It is always of greater interest to know why men work and at which level and how he / she satisfied with the job. ${ }^{13}$

In present study, 24 (48\%) ASHA were aware about their role of ANC registration and Health education regarding the health schema. $9(18 \%)$ ASHA's were unable to get cooperation from people, 22 (44\%) ASHA's had problem that people do not trust on them, 11 (22\%) ASHA had problem regarding travelling facilities and 8 (16 \%) ASHA had workload of their duty whereas in Dagar $\mathrm{N}$ et cl. conducted study on problem faced by ASHA workers in New Delhi and found that most of ASHA were aware of their role regarding $\mathrm{MCH}$ care, referral and escort, health education and elderly care but only one ASHA mentioned about their role in sanitation of the community. ${ }^{14}$

In present study, the findings were 33 (66\%) of ASHA workers were satisfied with their job, 3 (6\%) ASHA workers were strongly satisfied with their job and 14 (28\%) ASHA workers were neutral and no ASHA worker was dissatisfied with her job. It concluded that large numbers of ASHA workers were satisfied with their job whereas in Mrs. Ruhi Varghese et. cl. conducted study on to assess the job satisfaction among ASHA workers of Waghodia taluka and their finding was $25 \%$ of ASHA workers were dissatisfied with their job and $75 \%$ of ASHA workers were satisfied with their job. It concluded that large number of ASHA workers were satisfied with their working condition and there by satisfied with their job. ${ }^{14}$

The study finding was limited to a selected area for the study. 


\section{CONCLUSIONS}

The study revealed the difficulties of scarcity of resources, irregular incentives, workload, non-materialisation of things, failure to achieve target, inadequate support from leaders, and no value for ASHAs. Most of the ASHAs felt that they were efficient to perform their routine job responsibility, although, fair number of ASHAs were not satisfied with their performance-based incentives. To overcome this problem a similar study may be conducted on a larger population for generalisation of findings. Studies may be carried out to assess the effectiveness of information booklet versus another method of teaching job responsibilities to ASHA worker and quality training programs provided regarding sensitising and motivating ASHAs for improving their performance.

Data sharing statement provided by the authors is available with the full text of this article at jemds.com.

Financial or other competing interests: None.

Disclosure forms provided by the authors are available with the full text of this article at jemds.com.

\section{REFERENCES}

[1] Lehmann U, Sanders D. Community health workers: what do we know about them? Geneva: World Health Organization 2007: p. 34.

[2] Bajpai N, Ravindra DH. Improving the performance of accredited social health activists in India. New York: Columbia University 2011:40-1.

[3] National Rural Health Mission. 6th Common review mission report 2012. New Delhi: National Rural Health Mission. Ministry of Health \& Family Welfare, Government of India 2012:36-8.

[4] Kamalam S. Community health nursing. $1^{\text {st }}$ edn. New Delhi: Jaypee Publisher 2011:86-9.
[5] Gulani KK. Community health nursing. $2^{\text {nd }}$ edn. Delhi: Kumar Publisher 2012:87-90.

[6] Das A, Dasgupta A. All India institute of hygiene and public health. Kolkata: General Science Sci Journal Impact Factor 4.016.

[7] Scott K, George AS, Ved RR. Taking stock of 10 years of published research on the ASHA programme: examining India's national community health worker programme from a health systems perspective. Health Research Policy and System 2019;17:29.

[8] Guha I, Raut AV, Maliye CH, et al. Qualitative assessment of accredited social health activists (ASHA) regarding their roles and responsibilities and factors influencing their performance in selected villages of Wardha. International Journal of Advanced Medical and Health Research 2018;5(1):21-6.

[9] Waskel B, Dixit S, Singodia S, et al. Evaluation of ASHA program in selected block of RAISEN district of Madhya Pradesh under the national rural health mission. J Evol Med Dental Serv 2014;3(3):689-94.

[10] Srivastava DK, Prakash S, Adhish V, et al. A study of interface of ASHA with the community and the service providers in Eastern Uttar Pradesh. Indian J Public Health 2009;53(3):133-6.

[11] Joseph S. Srivastava SC. Social acceptance and job satisfaction of ASHA workers in the Garo Hills Division of Meghalaya: a cross - sectional study. Int J Community Med Public Health 2019;6(9):3705-9.

[12] Das A, Dasgupta A. An exploratory analysis of knowledge and practice, job - related difficulties and dissatisfaction of ashas in rural India. Int J Cur Res Rev 2015;7(10):1419.

[13] Ruhi V, Swamy PGN, Jigisha C. Community health nursing - a study to assess the level of job satisfaction among ASHA workers of Waghodia Taluka. Asian J Nursing Education and Research 2018;8(2):209-12.

[14] Dagar N, Bhardwaj U, Bansal P. The problems faced by ASHA's (accredited social health activist) - a qualitative study. Journal of Nursing Science and Practice 2017;7(2):25-30. 